\title{
Microfouling on biocidal and non-biocidal antifouling coatings
}

\author{
Thirumahal Muthukrishnan ${ }^{1 *}$ and Sergey Dobretsov ${ }^{1}$
}



ABSTRACT. Although antifouling marine paints have been used to prevent biofouling, not much is known about their effectiveness in preventing attachment of microorganisms. The current study aims at estimating the abundance of bacteria within biofilms developed on various commercial antifouling coatings in Marina Bandar Rowdha and Marina Shangri La, Oman. Coatings tested included Pettit \#1863 and \#1792, West Marine \#11046620, \#5566252 and \#10175206, Hempel Hard Racing \#76484, Hempel Olympic \#86950, Hempasil X3 and International YBA920. All coatings were applied on clean plastic slides. Slides without any coating were used as controls. Microbial biofilms were harvested after 2, 7 and 14 days of biofouling. Bacterial density was estimated using epifluorescence microscopy. There was a significant difference between the various treatments (coatings and control) after 2, 7 and 14 days of biofouling. Although there were significant differences between both locations after 2 and 14 days of biofouling, no significant difference was observed after 7 days of biofouling at both locations. At Shangri La, the lowest bacterial density was found on International YBA920, Pettit \#1792 and Hempasil X3 after 2 days, 7 days and 14 days respectively in comparison to the control treatments. However at Bandar Rowdha, International YBA920 showed the lowest bacterial density after 2 days while West Marine \#10175206 showed the lowest bacterial density after both 7 days and 14 days of biofouling in comparison to the control treatment. The differential performance of tested antifouling coatings may be attributed to several factors including varying environmental conditions, difference in microfouling communities, time of exposure and physical and chemical properties of antifouling coating.

Keywords: Coatings, antifouling, microfouling, bacteria, phototrophic.

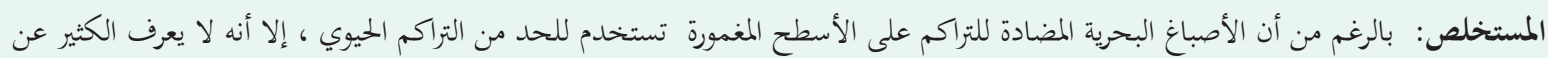

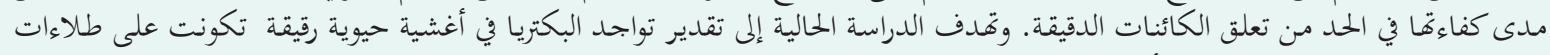

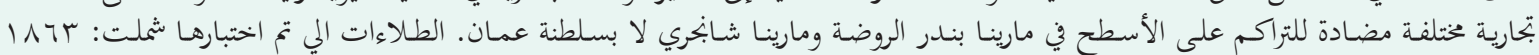



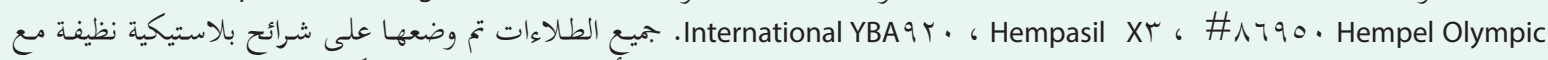

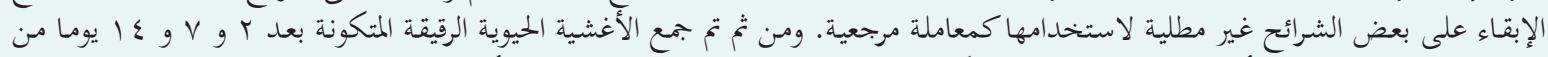



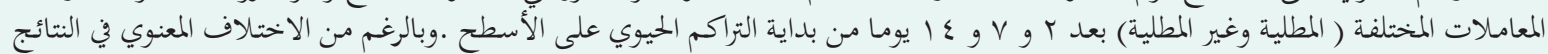

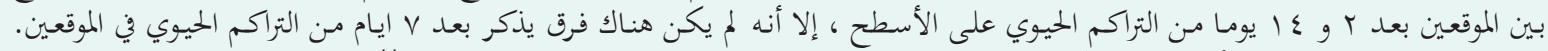

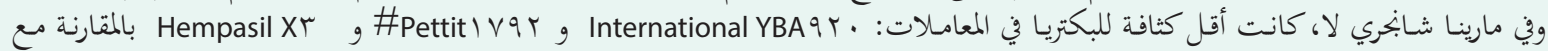

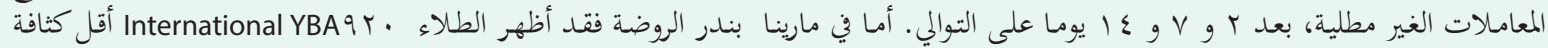

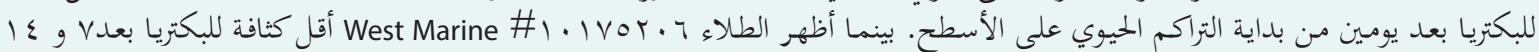

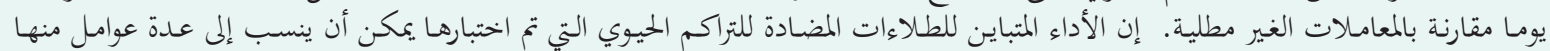

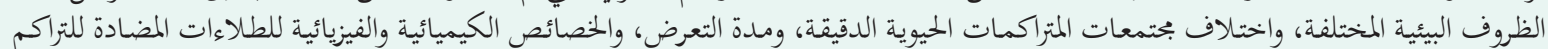
على الأسطح. الكلمات المفتاحية: الطلاءات ، مضادات التراكم الحيوي على الأسطح ، التراكم الحيوي للكائنات الدقيقة، البكتريا، الإبحذاب للضوء

\section{Introduction}

$\mathrm{B}$ iofouling has been a major problem in several marine industries including the shipping industry. Hull fouling adversely affects hydrodynamic drag

\footnotetext{
"1 Thirumahal Muthukrishnan $(\Varangle)$ Sultan Qaboos University, College of Agricultural and Marine Sciences, Department of Marine Science and Fisheries. Box 34, Al-Khod 123. Sultanate of Oman. email: mthirumahal@hotmail.com
}

leading to elevated fuel consumption and higher maintenance costs although the impact of biofilms is significantly less than that of macrofouling (Yebra et al. 2004; Schultz 2007; Schultz et al. 2011). In marine environments, formation of biofilms (ie microfouling) depends on the types of fouling microorganisms, environmental factors such as current, temperature, salinity, nutrient levels and hydrodynamic conditions (Wieczorek and Todd 1998 ; Lau et al. 2005; Zhang et al. 2011) and properties of substratum (Whitehead and Verran 2008). Mi- 
A

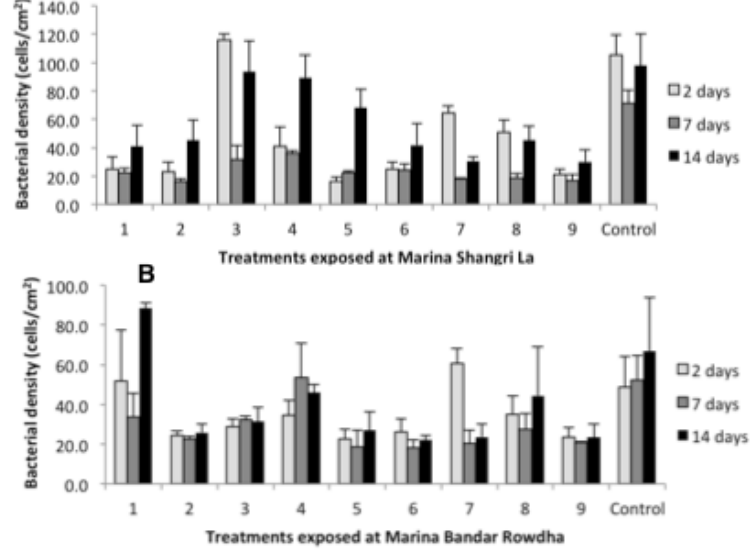

Figure 1. Bacterial density in biofilms developed on all treatments (Coatings 1-9 and Control) after 2, 7 and 14 days of biofouling at (A) Marina Shangri La and (B) Marina Bandar Rowdha . Data are the means + SD $(n=3)$.

crobial fouling communities consist mainly of numerous species of bacteria and diatoms that can positively and/ or negatively interact with each other (Railkin 2003; Dobretsov 2010). Both bacteria and diatoms may also have a significant impact on the recruitment of invertebrate larvae and algal spores (macrofouling) by either enhancing or inhibiting their settlement (Mitchell and Maki 1988; Maki 2002; Huang and Hadfield 2003; Qian et al. 2007; Hadfield 2011). This significantly influences the extent to which biofouling occurs in the marine environment. However bacteria have generally been accepted to be the primary colonizers on man-made surfaces in the marine environment (Molino et al. 2009b). Therefore it is important to study the efficiency of antifouling coatings in preventing bacterial fouling during the primary stages of biofouling in the marine environment. The objective of the current study was to estimate the abundance of bacteria within biofilms developed on various commercial antifouling coatings at two different locations in Oman. The hypothesis tested was that treatments (nine commercial antifouling coatings) and location influence the abundance of bacteria within biofilms developed on commercial antifouling coatings.

\section{Materials and methods}

\section{Coatings preparation}

Six commercial antifouling coatings (Petit \# 1863, Petit 1792, West Marine \#5566252, West Marine \#11046620, West Marine \#10175206 and International Micron Extra YBA 920) were obtained at local boat shop (Muscat, Oman). Three commercial antifouling coatings (Hempel Hard Racing 76484-51170, Hempel Olympic 86950-
5110 and Hempasil X3) were obtained from Hempel Ltd. Co. (Muscat, Oman). The nine antifouling coatings (Table 1) were manually applied onto cleaned, acrylic plastic slides $(75 \times 25 \mathrm{~mm})$ at Marine Science and Fisheries Laboratory, Sultan Qaboos University, Oman. All coated slides were dried for several hours at ambient temperature prior to deployment. Uncoated cleaned plastic slides were considered to be the control treatments. For each treatment including control, a total of 18 replicate slides were prepared.

\section{Coatings Deployment}

A total of 180 slides were randomly inserted into 6 slide cassettes (each $21 \times 16 \times 3 \mathrm{~cm}$ ) such that each slide cassette contained 3 replicates of each treatment and 30 equally spaced slides in total. Each slide cassette was deployed by ropes such that each slide in the slide cassette was kept vertical with respect to the surface of seawater. Three slide cassettes were deployed each at Marina Shangri La (Muscat, Oman 23 32' 55” N 58 39' 23" E) and Marina Bandar Rowdha (Muscat, Oman $23^{\circ} 34^{\prime} 55^{\prime \prime} \mathrm{N} 58^{\circ} 36^{\prime} 27^{\prime \prime} \mathrm{E}$ ).

\section{Sample collection}

Each of the three slide cassettes at Marina Bandar Rowdha and Marina Shangri La were withdrawn after 2 days, 7 days and 14 days of biofouling respectively. During sample collection, all slides from the slide cassette were carefully transferred into clean plastic boxes containing formalin (3.7\% final concentration) and immediately transferred to the laboratory at $4^{\circ} \mathrm{C}$ for further analysis (see below).

\section{Estimating abundance of bacteria}

The total bacterial density on the treatment surfaces was estimated by staining an area of $2 \times 2 \mathrm{~cm}$ with 10-12 $\mu \mathrm{l}$ of 4, 6-diamidino-2-phenylindole (DAPI, Sigma, Germany) solution for 15 minutes according to Dobretsov and Thomason (2011). The number of bacteria in 10 randomly selected fields of view on the ocular grid $\left(0.001 \mathrm{~mm}^{2}\right)$ was counted using an epifluorescence microscope (Axiostar plus, Zeiss, Germany; magnification $\left.1000 \mathrm{x} ; \lambda_{\mathrm{Ex}}=359 \mathrm{~nm}, \lambda_{\mathrm{Em}}=441 \mathrm{~nm}\right)$.

\section{Statistical analysis}

Factorial ANOVA was used to test the effect of treatment and location on the total bacterial density using Statistica 11 (Statsoft, USA) after 2, 7 and 14 days of biofouling. Post hoc HSD test was used to test for significant differences among the treatments and locations. In all cases, the threshold for significance was 0.05 .

\section{Results}

The treatments (antifouling coatings and control) significantly influenced the bacterial density in biofilms developed after 2, 7 and 14 days of biofouling (Figure $1 \mathrm{~A}$ and Figure 1B; ANOVA, HSD, P < 0.0001). Although 
Table 1. Characteristics of the ten treatments exposed to biofouling at depth, $1 \mathrm{~m}$ at Marina Shangri La and Marina Bandar Rowdha.

$\begin{array}{llll}\text { Treatment } & \text { Commercial coating } & \text { Type of coating } & \text { Active Ingredient } \\ 1 & \text { Petit Marine \#1863 } & \text { Biocidal } & \text { Zinc pyrithione } \\ 2 & \text { Petit Marine \#1792 } & \text { Biocidal } & \text { Pure Zinc } \\ 3 & \text { West Marine \#5566252 } & \text { Biocidal } & \text { Cuprous Thiocyanate } \\ 4 & \text { West Marine \#11046620 } & \text { Biocidal } & \text { Zinc pyrithione } \\ 5 & \text { International micron extra YBA920 } & \text { Biocidal } & \text { Cuprous oxide + Dichlofluanid } \\ 6 & \text { West Marine \#10175206 } & \text { Biocidal } & \text { Cuprous oxide } \\ 7 & \text { Hempel Hard Racing \#76484-51170 } & \text { Biocidal } & \text { Cuprous oxide } \\ 8 & \text { Hempel Olympic \#86950-51110 } & \text { Biocidal } & \text { Copper } \\ 9 & \text { Hempasil X3 } & \text { Non-biocidal } & \text { Silicone } \\ \text { Control } & - & - & \text { - }\end{array}$

both locations were found to significantly affect bacterial density after 2 and 14 days (ANOVA, HSD, P < $0.0001)$ there was no significant difference between both locations after 7 days of biofouling (ANOVA, HSD, P = 0.237). However both treatments and locations together significantly affected the bacterial density in biofilms after 2, 7 and 14 days of biofouling (ANOVA, HSD, P $<0.01$ ). At Shangri La, the lowest bacterial density was found on International YBA920, Pettit \#1792 and Hempasil X3 after 2 days, 7 days and 14 days respectively in comparison to the control treatments (Figure 1A). However at Bandar Rowdha, International YBA920 showed the lowest bacterial density after 2 days while West Marine \#10175206 showed the lowest bacterial density after both 7 days and 14 days of biofouling in comparison to the control treatment (Figure 1B). The differential performance of tested antifouling coatings may be attributed to several factors including varying environmental conditions and differences in the abundance of fouling bacterial communities. The variation in the concentrations of biocides in these coatings may be additional factor in influencing bacterial attachment on coatings. In particular the polishing rate behavior and biocide delivery rate behavior is known to vary for different coating types (Finnie \& Williams 2010, Bressy et al. 2010). Clearly further investigations are required to study the abundance and composition of bacterial fouling communities on antifouling coatings.

\section{Conclusions}

The current study shows that the abundance of bacteria in biofilms developed on commercial antifouling coatings is significantly influenced by the coating types and both coatings and location together after 2, 7 and 14 days of biofouling. Varying environments were not found to affect the bacterial density after 7 days of biofouling although there were significant differences after 2 and 14 days of biofouling.

\section{Acknowledgements}

This study was supported by HM Sultan Qaboos Research Trust Fund SR/AGR/FISH/10/01. The authors thank Hempel Ltd. Co. (Muscat, Oman) for providing coatings. The authors would also like to thank Ms. Annika Vaksmaa (Sultan Qaboos University) for her assistance in experimental setup.

\section{References}

Bressy, C., C., Hellio, J.P., Marechal, B., Tanguy, and A., Margaillan. 2010. Bioassays and field immersion tests: a comparison of the antifouling activity of copper-free poly(methacrylic)-based coatings containing tertiary amines and ammonium salt groups. Biofouling 26: 769-777.

Dobretsov S. 2010. Marine biofilms. In: Biofouling, Dürr S, Thomason JC, editors. Wiley-Blackwell, Oxford (UK): 123-136.

Finnie AA, and D. N. Williams. 2010. Paint and Coatings Technology for the Control of Marine Fouling. In: Biofouling, Dürr S, Thomason JC, editors. Wiley-Blackwell, Oxford (UK).

Hadfield M. 2011. Biofilms and marine invertebrate larvae: what bacteria produce that larvae use to choose settlement sites. Annual Review of Marine Science 3: 453-470.

Huang S, Hadfield MG. 2003. Composition and density of bacterial biofilms affect

metamorphosis of the polychaete Hydroides elegans. Marine Ecology Progress Series, 260: 161-172.

Lau SCK, V., Thiyagarajan, SCK, Cheung, and P-Y Qian. 2005. Roles of bacterial community composition in biofilms as a mediator for larval settlement of three marine invertebrates. Aquatic Microbial Ecology 38: 41-51.

Maki JS. 2002. Biofouling in the marine environment. In: 
Encyclopedia of Environmental Microbiology, Bitton G, ed. (New York: John Wiley \& Sons) pp 610-619.

Mitchell R., and JS Maki. 1988. Microbial surface films and their influence on larval settlement and metamorphosis in the marine environment. In: Marine Biodeterioration: Advanced Techniques Applicable to the Indian Ocean, Thompson M-F, Sarojini R, Nagabushanam R, eds. (New Delhi: Oxford \& IBH) pp 489-497.

Molino PJ, S., Childs, MR, Eason Hubbard, JM, Carey, MA, Burgman, and R., Wetherbee. 2009b. Development of the primary bacterial microfouling layer on antifouling and fouling release coatings in temperate and tropical environments in Eastern Australia. Biofouling 25: 149-162.

Qian P-Y, SCK, Lau, H-U, Dahms, S, Dobretsov, and T., Harder. 2007. Marine biofilm as mediator of coloni- zation by marine macroorganisms: implications for antifouling and aquaculture. Marine Biotechnology 9: 399-410.

Railkin AI. 2003. Marine biofouling: colonization processes and defenses. Boca Raton (FL): CRC Press. 320 pp.

Schultz MP. 2007. Effects of coating roughness and biofouling on ship resistance and powering. Biofouling 23: 331-341.

Schultz MP, JA Bendick, ER Holm, and WM Hertel. 2011. Economic impact of biofouling on a naval surface ship. Biofouling 27: 87-98.

Wieczorek SK, and CD Todd. 1998. Inhibition and facilitation of settlement of epifaunal marine invertebrate larvae by microbial biofilm cues. Biofouling 12: 81118.

Yebra DM, S Kiil, and K Dam-Johansen. 2004. Antifouling technology: past, present and future steps towards efficient and environmentally friendly antifouling coatings. Progress in Organic Coatings 50: 75-104. 